\title{
Return of State Losses in Corruption through Confiscation of Assets Based on Justice (Indonesian Perspective)
}

\author{
Isharyanto \\ Faculty of Law \\ Sebelas Maret University \\ Surakarta, Indonesia
}

\begin{abstract}
Confiscation of assets to recover state losses in a criminal act of corruption requires proof of the value of state losses or the results obtained from criminal acts of corruption, either directly or indirectly, and even includes an increase in value due to appreciation. Confiscation of assets is a legal step required in the framework of the functionalization of criminal law to restore justice because criminal acts of corruption are related to protecting public rights related to state assets. Therefore, this step is following the idea of justice to achieve the real goal of the law.
\end{abstract}

Keywords:- Corruption, Asset Recovery, Indonesia, Criminal Law.

\section{INTRODUCTION}

In general, there are three main issues in eradicating criminal acts of corruption, namely (i) prevention; (ii) eradication; and (iii) asset recovery. The crime of corruption is directly or indirectly detrimental to the State's finances or the country's economy, which at the same time harms the people.[1] The victims of corruption crimes are the State and the people because, with the existence of corruption crimes, the country's finance and the economy will be reduced and disturbed.[2] The corruptors make the State victims. The corrupted state assets are narrowly detrimental to the State and detrimental to the State at large.[3]

Several criminals were sentenced to fines but later chose to be replaced by imprisonment. It means that state losses are not recovered.[4] Recently, in Indonesia, the idea of impoverishment for corruptors has emerged by being punished with the obligation to return several state losses. [5] However, through the current criminal procedural law, the formal procedural approach has not been able to recover state losses. Even though state losses caused by corruption are state assets that must be saved.[6] Therefore, other ways are needed to save these state assets, namely by returning the perpetrators' assets.

If there is an instrument of expropriation of assets, it is possible, first, at least perhaps the perpetrator will think of committing a criminal act because it will not benefit or the profit will be confiscated for the State.[7] Second, the criminal loss of independence (imprisonment) will not prevent the committing of a criminal act because the perpetrator can still enjoy the proceeds/benefits of the crime.[8] Third, the confiscation of assets can increase community support and serve as an important message that the government is serious about fighting crime.[9] Fourth, the confiscation of assets is a reflection of supporting the conduct of the war against specific crimes.[10] Fifth, the fines have been imposed on the perpetrators are considered insufficient to deter a criminal act.[11] Sixth, the confiscation of assets serves to warn those who want to commit crimes.[12]

The recovery asset is a series of processes or stages starting from collecting information or intelligence materials, evidence and tracking of assets, freezing of assets and confiscation of assets, court proceedings, implementation of court decisions or decisions, and assets return. The recovery of assets as a process, through investigation process to trial, requires proof so that an asset can be confiscated and confiscated for the State. The success of proving an asset as a criminal asset can support efforts to recover assets.[13]

In Indonesia, the return of assets has been pursued through the criminal procedure law mechanism by executing replacement money and civil instruments. However, research conducted by Agustinus Herimulyanto has confirmed that these efforts have not been optimal. It is because a large number of state losses have not been returned.[14]

For this reason, one of the proposed mechanisms is through the act of confiscating assets. Through the evidentiary stage, confiscated assets are expected to be confiscated for the State to recover the losses. However, the challenge that immediately arises is evidence to produce information that links assets to criminal acts of corruption. Meanwhile, the success of proof requires sufficient evidence.

This paper attempts to describe the legal issues related to the criminal act of corruption's confiscation of assets. An analysis is then carried out using the concept of justice as an objective variable to provide an assessment of the idea of 
confiscation of assets related to the criminal act of corruption.

\section{DISCUSSION}

\section{Legal Problems and Development}

Asset recovery is the process of handling the proceeds of crime in an integrated manner at every stage of law enforcement so that the value of these assets can be maintained and fully returned to victims of crime, including to the State. Asset recovery also includes all preventive measures to prevent the asset's value from being reduced. The stolen asset recovery is significant for developing countries because it is not merely restoring state assets but also aims to uphold the rule of law where no one is immune to the law.

The principle of asset recovery is explicitly stipulated in the Anti-Corruption Convention. The provisions of Article 51 of the Anti-Corruption Convention technically allow prosecution, both civil (through lawsuits) and criminally, to return state assets that have been obtained by someone through corruption. Meanwhile, in Indonesia, the Anti-Corruption Law provides two ways to confiscate assets resulting from a crime that causes financial or economic losses to the State. The two routes are seizure through criminal channels and seizure through civil lawsuits.

As described in the introduction to this paper, both methods have been implemented but have not given optimal results. Therefore, the idea emerged to confiscate assets to recover state losses. The essence of this action is that a criminal act has harmed the State. In this context, the perpetrator must recover by returning or compensating for the loss and not to enjoy the proceeds of the criminal act of corruption.

In Indonesia, according to Article 1 point 16 of the 1981 Criminal Code, confiscation is defined as being limited to "for evidentiary purposes" and not for the return of assets, so it cannot be applied if it is linked to the purpose of returning the assets. According to the procedural law, the confiscation was sufficient for the reason "strongly suspected" that it was related to a criminal act. Therefore, the provisions in the procedural law are general principles that must be upheld. The deviation is only possible if there is a specific law and then negates the provision.

Confiscation of assets requires "sufficient evidence," so it is different from confiscation in general that is related to a criminal case. However, this "sufficient evidence" can serve as a guideline for the confiscation of assets in asset recovery, especially if the evidence is in the hands of the public prosecutor. Then, the public prosecutor can use the provisions of Article 39 paragraph (1) of the Criminal Code relating to objects related to criminal acts. In this provision, confiscation of goods can be carried out if they have the following relationships: (i) ownership relationship between the goods and the convicted person; and (ii) relations as goods obtained from crime or relations as goods used to commit crimes. However, it should be noted that the definition of "objects," according to the Criminal Code, does not include intangible objects. Apart from that, linguistically speaking, it is not sufficient to understand whether the said "thing" must be in a physical sense or include the meaning of value. It is essential to provide certainty in the context of confiscation in order to return assets.

Meanwhile, Article 18 paragraph (1) of the 1999 AntiCorruption Law goes further by defining objects as movable objects or immovable objects that are "used" or "obtained from criminal acts of corruption," including companies owned by the convict in which the crime is committed. Done, as well as the price of the goods that replace the goods. In this context, the law provisions have changed the nature of objects to be value-based, seen from the clause "the price of the goods that replace these goods." Chazawi explained that in the criminal law of corruption, it could impose a crime of confiscation of intangible goods and the price (money) of the goods confiscated. It is done if, for some reason, it cannot be seized; for example, an object cannot be found or has been destroyed by the perpetrator. If this definition is followed, then expropriation may include assets acquired before the criminal act of corruption was committed.

Provisions in the anti-corruption law do not provide a clear framework for "seize the benefits" of an increase in value due to the appreciation of an asset from a criminal act of corruption. However, in practice, the Supreme Court in decision Number 1473K / Pid. Sus / 2016, dated 30 November 2016, has taken over this definition with a definition that includes "state losses that occur are the loss of benefits equal to the value of assets that should be received."

\section{Justice Perspective}

From a theoretical perspective, it is generally accepted that criminal law is necessary to prevent seriously threatening or harmful behavior. This view is understandable but conceptually simplifies the problem too. If followed, this definition can guide by giving freedom that anything deemed dangerous can be prohibited. Through this observation, a threat at a deep level does not in itself become a criterion for categorizing an action as a criminal act.

However, experts also agree that criminal law is needed to achieve a big goal, namely restoring justice. With this argument, it becomes a strong knowledge base for seeking punishment procedures to the maximum extent, especially if the crime is committed against the ownership of assets full of public interests such as state finances.

Baharudin Lopa stated that the criminal act of corruption is a criminal act committed by bribery of manipulation and illegal acts that are detrimental or detrimental to state finances or the country's economy, detrimental to the welfare or interests of the people.[15] Corruption is a crime of calculation that uses thoughts rather than being driven by emotions. Understanding the aspects of corruption and their causes in the context of a particular 
situation makes anti-corruption reform feasible. This movement is carried out in two stages. First, formulating policies to deal with the causes of corruption. Second, creating a political will, which is crucial for the anticorruption reform movement.[16] Corruption must be overcome immediately in a variety of rational and measured ways.[17] Returning assets is one of the new punishments in criminal law to eradicate corruption.

From the perspective of corruption eradication, assets' return is generally considered a tool or means of fighting profit-oriented crimes, including acquisitive crimes (crimes are driven by greed) and organized crime. In practice and the most general terms, the return of assets resulting from a criminal act of corruption is a multi-stage process and branches of several complexities, covering some institutions, including the police (in a broad sense including the police, prosecutors, courts, customs, and investigative agencies. others).

The author considers it essential to create and formulate a legal theory called the theory of return on assets because, as Oliver Wendel Holmes said, a theory is the most crucial part of the law, as an architect in building a house, theory gives shape, which according to Rudolf Von Jhering is rooted in essence most profound of the law.[18] Asset return theory is an attempt to bring economic justice. Justice in the context of a judge's decision can be seen from two sides: procedural justice and substantive justice. Procedural justice is justice related to protecting human rights and legal rights of the parties (suspects, defendants, witnesses, and victims) in every stage of the judicial process regulated by law. Substantive justice is justice related to a judge's decision to examine, try, and decide a case based on honesty, objective, and moral considerations.[19] Every formal juridical decision of a judge cannot ignore the procedural aspects, but the most important of all is the birth of a decision that can lead the judges to the real legal objectives, namely justice, usefulness, and legal certainty.[20]

The problem that arises in the effort to recover assets (asset recovery) in cases of corruption is the decision of a judge who attempts to impose an additional penalty in the form of payment of replacement money but always collides with the economic situation of the convict who is unable to pay the replacement money in full. As a result, the substitute money punishment as an effort to recover assets is substituted for imprisonment, so that the judge's decision cannot realize the hope of achieving economic justice. Barda Nawawi Arief explained that the strategy for criminalization policies in crimes with a new dimension must pay attention to the problem's nature. If the essence of the problem is closer to the problems in economic law, then the use of fines or the like is preferred. Determination of criminal sanctions should be carried out through a rational approach. If it is based on this rational concept, the policy to determine criminal sanctions is inseparable from setting the objectives to be achieved by the overall criminal policy.[21]
The problem of asset recovery on corruption is confronted with the reality of the convict's inability to pay the penalty for compensation, which is normatively allowed in the law. There are still hidden assets belonging to the convict that has not been confiscated by law enforcement. This reality is not in line with asset recovery, which is loyal to the principle of "giving the country what its right is." As a result, economic justice cannot be achieved because the convict chooses to undergo subsidiary punishment, and the State continues to suffer losses. Besides, there is a mismatch between the substitute money that must be paid, and the subsidiary penalties served.

\section{CONCLUSION}

Confiscation of assets to recover state losses in a criminal act of corruption requires proof of the value of state losses or the results obtained from criminal acts of corruption, either directly or indirectly. For this reason, confiscation can reach the object of confiscation inform value of benefits or gains from the criminal act of corruption, even including the increase in value due to appreciation. Confiscation of assets is a legal step required in the framework of criminal law's functionalization to restore justice. This step is significant because the criminal act of corruption is related to protecting public rights related to state assets. Therefore, this step is following the idea of justice to achieve the real goal of the law.

\section{REFERENCES}

[1]. T. Bagashka, "Unpacking Corruption: The Effect of Veto Players on State Capture and Bureaucratic Corruption," Polit. Res. Q., vol. 67, no. 1, pp. 165180, Jul. 2013, doi: 10.1177/1065912913492584.

[2]. F. Battaglia, M. Carboni, A. F. Cicchiello, and S. Monferrà, "Assessing the Effects of Anti-corruption Law on Entrepreneurial Finance: Evidence from Latin America," J. Emerg. Mark. Finance, p. 0972652720932783, Jul. 2020, doi: 10.1177/0972652720932783.

[3]. M. Hajdu, B. Pápay, Z. Szántó, and I. J. Tóth, "Content analysis of corruption coverage: Crossnational differences and commonalities," Eur. J. Commun., vol. 33, no. 1, pp. 7-21, Jan. 2018, doi: 10.1177/0267323117750673.

[4]. M. Fazekas and I. J. Tóth, "From Corruption to State Capture: A New Analytical Framework with Empirical Applications from Hungary," Polit. Res. Q., vol. 69, no. 2, pp. 320-334, Mar. 2016, doi: 10.1177/1065912916639137.

[5]. Indah Mahniasari, "Konfigurasi Politik dalam Pemberantasan Tindak Pidana Korupsi," Al-Risal., vol. 13, no. 01, pp. 153-168, 2013, doi: 10.30631/alrisalah.v13i01.445.

[6]. S. Zyglidopoulos, P. Hirsch, P. Martin de Holan, and N. Phillips, "Expanding Research on Corporate Corruption, Management, and Organizations," $J$. Manag. Inq., vol. 26, no. 3, pp. 247-253, May 2017, doi: $10.1177 / 1056492617706648$. 
[7]. T. Vorley and N. Williams, "Between petty corruption and criminal extortion: How entrepreneurs in Bulgaria and Romania operate within a devil's circle," Int. Small Bus. J., vol. 34, no. 6, pp. 797-817, Jul. 2015, doi: $10.1177 / 0266242615590464$.

[8]. D. Prateeppornnarong, "Fighting Corruption While Having Hands Tied: A Case Study of Thailand's Public Sector Anti-Corruption Commission," J. Asian Afr. Stud., p. 0021909620926529, May 2020, doi: $10.1177 / 0021909620926529$.

[9]. P. Riley and R. K. Roy, "Corruption and Anticorruption: The Case of India," J. Dev. Soc., vol. 32, no. 1, pp. 73-99, Feb. 2016, doi: 10.1177/0169796X15609755.

[10]. J. W. Buttle, S. Graham Davies, and A. E. Meliala, "A cultural constraints theory of police corruption: Understanding the persistence of police corruption in contemporary Indonesia," Aust. N. Z. J. Criminol., vol. 49, no. 3, pp. 437-454, Mar. 2015, doi: $10.1177 / 0004865815573875$.

[11]. A. V. Orlova and V. Boichev, “'Corruption Is Us': Tackling Corruption by Examining the Interplay Between Formal Rules and Informal Norms Within the Russian Construction Industry," J. Dev. Soc., vol. 33, no. 4, pp. 401-427, Nov. 2017, doi: $10.1177 / 0169796 \times 17735238$.

[12]. H. Hobbs and G. Williams, "The case for a national whole-of-government anti-corruption body," Altern. Law J., vol. 42, no. 3, pp. 178-183, Sep. 2017, doi: 10.1177/1037969X17730190.

[13]. G. Pavlidis, "Towards more responsible international asset recovery: The European Union should lead the way," New J. Eur. Crim. Law, vol. 9, no. 3, pp. 300307, Sep. 2018, doi: 10.1177/2032284418802096.

[14]. A. Herimulyanto, Sita Berbasis Nilai Pengembalian Aset Tindak Pidana Korupsi: Teori dan Terapan Value-Based Confiscation System dalam Pemberantasan Tindak Pidana Korupsi. Yogyakarta: Genta Publishing, 2019.

[15]. Berdiansyah, "Analisis yuridis terhadap pengadaan barang dan jasa guna mencegah korupsi," J. Integritas, vol. 3, no. 2, pp. 79-104, 2017.

[16]. F. H. E. Nugroho, "Pemanfaatan Teknologi Informasi dalam rangka Memberantas Tindak Pidana Korupsi secara Elektronik," Din. Huk., vol. 14, no. 3, pp. 539546, 2014.

[17]. T. Santoso, "Menguak relevansi ketentuan grativikasi di Indonesia," Din. Huk., vol. 13, no. 3, pp. 402-414, 2013.

[18]. T. Prasetyo, Kriminalisasi dalam hukum pidana. Bandung: Nusa Media, 2010.

[19]. M. Syamsudin, "Rekonstruksi pola pikir hakim dalam memutuskan perkara korupsi berbasis hukum progresif," Din. Huk., vol. 11, no. 1, pp. 11-21, 2011.

[20]. Anshar, "Infra petita putusan pengadilan tindak pidana korupsi yang menerobos ketentuan pemidanaan minimum," J. Yudisial, vol. 11, no. 2, pp. $151-170,2018$.

[21]. B. N. Arief, "Pembaruan penegakan hukum dengan nilai-nilai moral religius," presented at the Seminar Nasional Menembus Kebuntuan Legal Formal
Menuju Pembangunan Hukum dengan Pendekatan Hukum Progresif, Semarang, 2009. 